\title{
Living with floods and land management strategies in Nepal
}

\author{
Zuzana Boukalova a, 1,2, Jan Těšitel ${ }^{2}$ and Binod Das Gurung ${ }^{3}$ \\ ${ }^{1}$ VODNÍ ZDROJE, a.s.; Jindricha Plachty 16, 15000 Prague 5, Czech Republic \\ ${ }^{2}$ METCENAS o.p.s.; Tleskacova 16, 32300 Plzen, Czech Republic \\ ${ }^{3}$ Czech University of Life Sciences, Kamycka 129, 16500 Prague 6, Czech Republic
}

\begin{abstract}
Land management is often addressed as a secondary matter in flood prevention, but should be given more attention. Land is a crucial factor in how societies and communities cope with changing flood risk, so policies must begin with land management to improve flood prevention and flood resilience. This is key issue for flood risk prevention as well in third countries. In our paper we are focusing on the research in Nepal and the question, how are the communities in Nepal living with floods and using nature-based flood mitigation measures on private and public land. We considered the flood like the basic unit of the analysis, in which three principal actors directly participate: 1) communities/villages affected by/living with flood; 2) pertinent institutions of regional/local administration, being in charge of "risk management" and "land management", and 3) NGOs, local to international, active in this field expertise and region. The main objective of this survey is to reveal behaviour of the three actors in particular phases of the situation (flood) and their attitudes to the flood. The research is aimed to achieve in-depth understanding on the situation as well as on factors supposed to influence /define it, particularly in the link to land management. As the basic method of the research, semi-structured interview were suggested for empirical data collection from the field, with the sample of respondents derived from the population by use of combination of purposeful and random sampling. Qualitative empirical data are processed by use of thematic analysis, the method used for identification of relevant themes and links among them. The field survey is realised in two model areas, in Kathmandu valley (representing urban environment) and in Tulsipur Sub-Metropolitan area (representing rural environment). Our research builds on the presumption that the process of adaptation/social learning is not universal, but place specific. Therefore, the hypothesis suggests, that thanks to the apparent differences existing between the model areas, adaptation strategies applied in Tulsipur are supposed to differ from that in Kathmandu.
\end{abstract}

\section{Introduction}

Nepal is exposed to a number of natural hazards. The most serious of them include floods, landslides, fires, and earthquakes. Therefore, on $24^{\text {th }}$ September 2017, the Nepal parliament passed a law that clearly defines a procedure for handling such risks at all levels of governance: from the central level to the level of each locality. The important components of this law include the principle of public awareness and a comprehensive approach towards risk management. For the first time in the history of Nepal, the state has assumed responsibility for flood risk management.

Based on this new situation, we were mainly interested in two things: how flood risk management is carried out directly on a local level in Nepal, and how feasible it is to align the use of technologies with public as well as private interests. In other words, we were wondering in what way technological processes were based on local, historically acquired knowledge, and how the city and country dwellers were involved in the entire process.
Our field survey focused on floods in big cities in the Kathmandu Valley and in rural Nepal, specifically in the Dang Valley.

\section{Kathmandu valley}

In the past, the water cycle management in big cities of Nepal, such as Kathmandu, Patan, and Bhaktapur was delicately interwoven with religious practices and feasts. Floods were an exceptional occurrence, rainwater was retained in the landscape and infiltrated through systems of artificial lakes (pokhari) and canals, at the same time using the semipermeable surface of the city's community squares, gardens and paths. At the same time, rainwater infiltration along with the exploitation of distant sources ensured sufficient recharge of the shallow aquifers that were used for supplying drinking as well as sanitary water to the population through systems of waterspouts (hiti) and wells.

\footnotetext{
${ }^{a}$ Corresponding author: author@e-mail.org

DOI 10.3311/FLOODRisk2020.10.1
} 
The inflow of migrants to big cities, which undermined the religious and traditional practices and, at the same time, brought about an increase in water demand as well as in land prices, led to a destabilisation of the water cycle. The city patterns gradually changed. The original pokhari were drained and used for construction. Farmland along rivers was built up, so that the rivers could not easily expand into the flood plains anymore during the monsoon season. Streets were made wider and covered with impermeable surfaces. The original rainwater infiltration systems were not maintained anymore and became clogged with garbage. The construction of new engineering infrastructure and water mains damaged the water supply systems for some hiti and disrupted the drainage of excess water in the process.

The "new" way of management of big cities in the Kathmandu Valley resulted not only in a shortage of drinking and sanitary water sources but also in local floods taking place in the monsoon period. At those times, rainwater accumulates in cities without a possibility of infiltration or drainage. Moreover, swelling rivers such as Bagmati in Kathmandu and Hanumante in Baktapur burst their banks and destroy the migrants' slums, which were built illegally on municipal land right on the riverbanks.

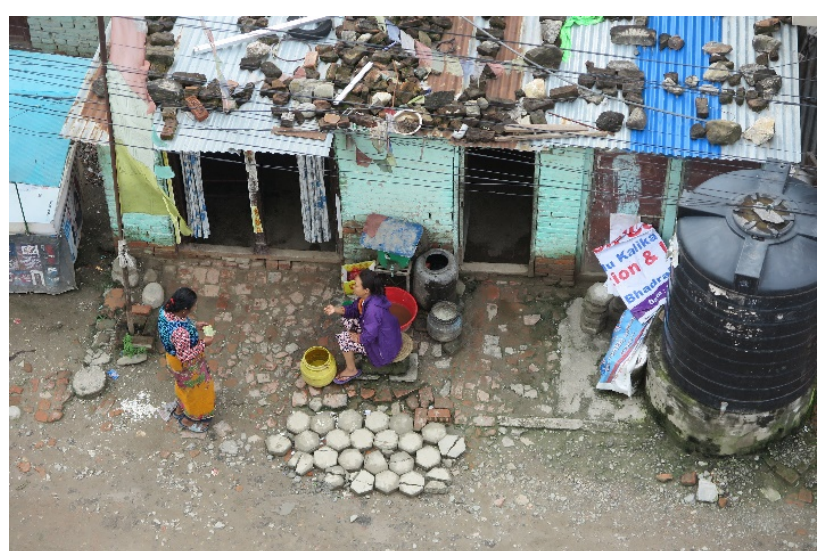

Figure 1. Buddha Nagar Toll Ward community

\subsection{Main problem - illegal settlements}

The issues of floods on private as well as municipal land in Kathmandu have been discussed and "experienced" by local communities for over 20 years. The state - or the municipality, for this matter - have been addressing floods on private and municipal land in the city of Kathmandu; however, entirely without taking into consideration migrants from other parts of Nepal who illegally occupy particularly the undeveloped municipal land on the banks of the Bagmati river, in an area of annually recurring flood risks. In the Kathmandu Valley, around 4,000 migrant families are now living grouped into 81 illegal settlement communities, out of which 74 are located directly in Kathmandu City. The majority of them are located in flood zones on municipal land, on which, upon their arrival, they settled without permission of the municipality (2019, reported orally by: Mr. Hukum Bahadur Lama, Chairperson of the Committee "Nepal Basobas Basti Samrakshan Manch", Nepal). Every year, these communities are flooded out of their makeshift dwellings, sometimes up to 3 times a year, especially in the monsoon period from June to September.

UN-Habitat has proposed for the temporary settlements the operational definition of a slum (UNHabitat, Chapter 1, 2010). According the definition, a slum household is defined as a household lacking one or more of the following: improved water; improved sanitation; sufficient living area; durable housing (location and permanency of structure) and secure tenure. Among these indicators, some are more distinctly applicable than others to characterise the temporal settlements in Kathmandu. For example, many temporal houses on the riverside of Baghmati are constructed using sacks, bamboo, plastic sheet, wood, metal sheet, mud and other temporary and semi-permanent materials. Some houses combine temporary and permanent material constructed with lowquality workmanship (Lumanti Support Group for Shelte; 2008).

The definition of a squatter settlement varies widely from country to country and depends on a variety of defining parameters. Generally, the squatter settlements are any collection of buildings in an urban locality where live the poor people, that has developed their homes without legal claims to the land and / or permission from the concerned authorities to build. The people are living there illegally and do not own the land. Because of the lack of legality, these settlements are not recognised by the administration and they do not have the formal address (Dangol N., Day J.; 2017).

In our research, we have focused on the question how these temporary settlements have been living with floods and dealing with them. On suggestion of the "slum king", Mr. Bahadur Lama, we have visited several of the most problematic communities in the vicinity of the Bagmati river and its tributaries, such as Jagriti Basti settlements (one of the oldest), Thapathaldi settlement (one of the most recent migrant community that has already been displaced twice by the municipality and the houses have been razed to the ground) and the Manohara settlement located in the potential future riverbed of the Manohara stream, which battles not only the floods but also erosion and the Kathmandu City urban management plan and their reallocation. In the settlements, not only migrants from all parts of Nepal live but also the poorest local people who cannot afford to buy a land plot in the city.

Migrants come to Kathmandu for different reasons (family disagreements, happier life, death in the family, political reasons); however, the main motive is seeking a job and better life. Since the time they first started to arrive many years ago, the state has been opposed to the illegal community development in the city. Back then, migrants used to settle in uninhabited areas outside the border of Kathmandu City, which subsequently spread over (the squatter community of Buddha Nagar Toll Ward was established on the Bagmati river bank in as early as 1973 (Boukalová, 2011, Figure 1).

The state even violently controls some of the squatters' activities. For example, until recently (year 2019) there was a Korean school for slum children on the territory of the Manohara settlements where 800-1000 households live. However, the government closed this school down, so that only a Care Centre operates on the 
premises of the former school where volunteers now look after the poorest children preparing meals for them 5 times a week. Most of the children now attend nearby state schools or are home-schooled, for instance in a small house of the Secretary of Nepal Basobas Basti Samrakshan Manch, Mrs. Bhagawati Karki

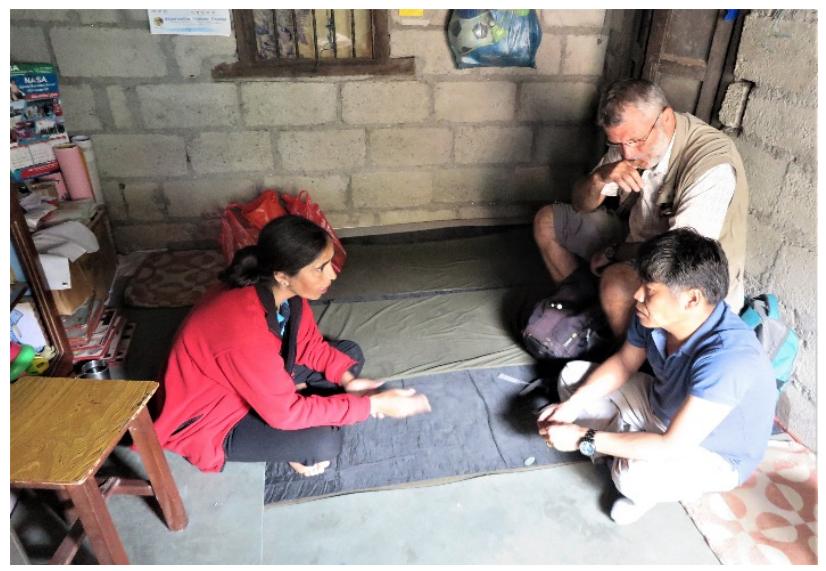

Figure 2. Discussion with Mrs. Bhagawati Karki

The government openly threatens to displace the communities and pull down their makeshift dwellings refusing to legalize them and, so far, it has not provided them with alternative accommodation, not even after they were flooded out. Although it helps for example to resettle refugees from Bhutan, it does not seem to care about the Nepalese migrants as such, and so far, there has not been a single "weapon" to help the migrants defend themselves, face the state and attempt to assert their rights.

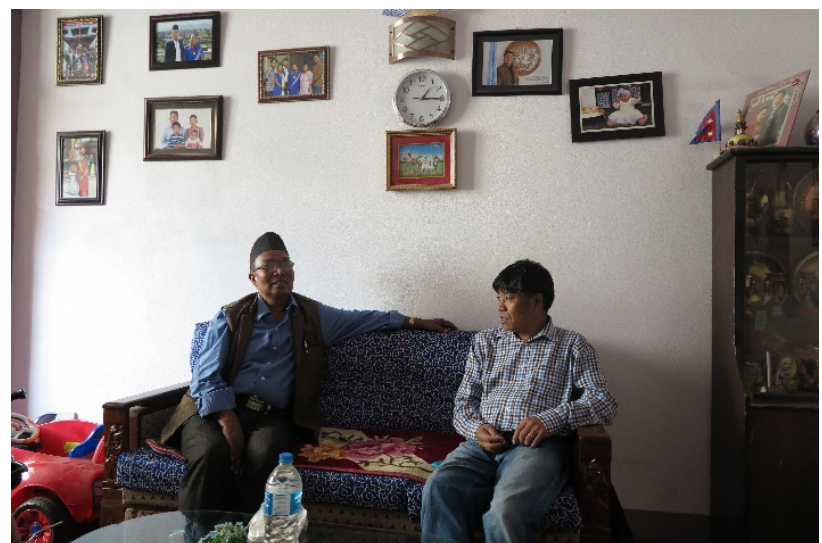

Figure 3. Discussion with "slum king”, Mr. Hukum Bahadur Lama

However, according to the "slum king", the situation is slowly starting to change. The squatters have established a very effective platform composed of all the community representatives (across the political spectrum), of which Mr. Hukum Bahadur Lama is the chairman. In 2019, the platform took advantage of its political power under the new communist government and set up a new strategy assuring the state that the inflow of migrants would not continue and the number of families in the squatter community would not grow. Based on this approach, a debate with the state is expected about delicate topics (especially about withdrawing the threat of displacing the squatters and destroying their temporary slums) as well as taking the case of squatter legalisation to the Nepalese court. The flooding of the migrants houses is as well between the discussed issues.

Even though the hopes of the squatters have greatly risen, and they believe in the solution of their situation, the course of the events is uncertain. In summer 2019, significant riverbed regulation works and the construction of levees at the site of Baneshwohr were started, in an area located just before the river enters the Jagriti Basti community settlement.

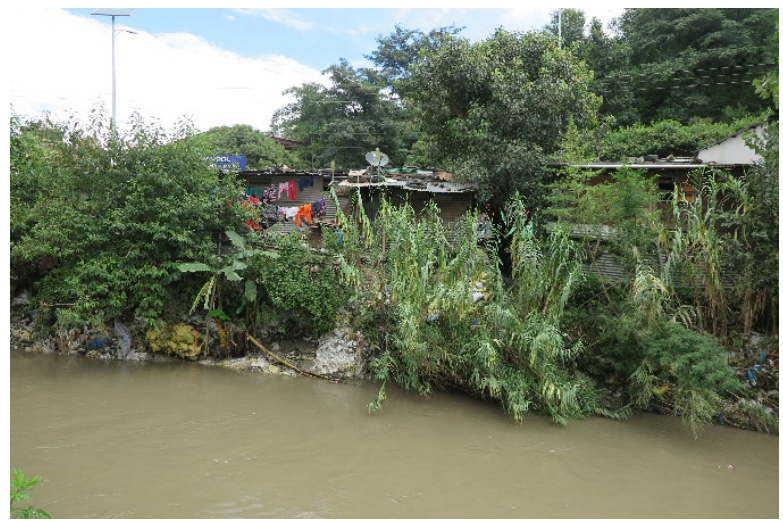

Figure 4. Jagriti Basti community settlement

What could this mean? The new riverbed modification will artificially straighten the river and contain it between the levees which reach a height of approx. $3 \mathrm{~m}$ (see images). Thanks to the new engineering structure, a foot bridge and a big road junction (Figure 5) adjacent housing will be protected but, in case of heavy rain, the river will flood the unprotected or poorly protected (bamboo walls cushioned with sacks with sand and clayey materials, see images - Figure 4) river banks beyond the bridge where the slum structures are located. Although the squatters are used to living with floods, the new construction - unless levees are built also in the area of Jagriti Basti - may mean permanent destruction of the slum community and even loss of lives. For the Jagriti Basti community, the trial against state concerning the legitimisation of its very existence may come too late.

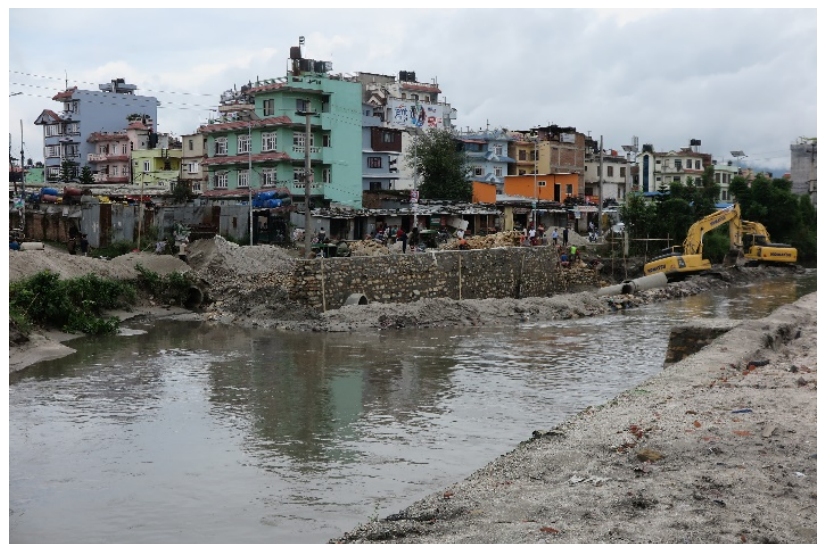

Figure 5. The new engineering structure

How is the situation seen by the community? Its members are beginning to realise the threat represented by 
the new engineering structure and the area where it has been situated by the government only increases the fear of displacement and loss of home. In this situation, they even start losing trust in their "king" and the representatives within the squatter platform fearing they may only fight for themselves and their personal interests. As a matter of fact, till now the committee has represented the squatters in a satisfactory way (although some level of corruption is probable), as it has an insight into the political processes as well as the needs of the communities. It raises funds from various non-governmental sources and foreign organisations, distributing them based on immediate needs either by way of direct "subsidies" for certain identified activities, or by organising work or purchases for those in need.

For the platform, floods are an important but not a priority issue. What is essential for the squatters is the legalisation of their residence and a right to the land and house they live in, although it may be in the flood zone. As land is expensive in the cities, it is impossible for them to acquire other life space than that in the slum.

Besides - such as in the case of the Jagriti Basti community - some houses in the slum are even being rented to the squatters, although they were built illegally on municipal land, either by the owners of adjacent land plots or even by other more affluent squatters who have built more houses in the "no man's land" and now make money by renting them.

This situation also increases the unwillingness of the state to grant the squatters a right to the slum house they are living in because it may involve a number of conflicts and a possibility that this measure will rather benefit the richer lessors than the poorest squatters.

The fight against floods has diverse forms in the various communities based on local situation and needs. The communities are trying to raise the land on which their houses are built and literally "tear it out" from the throat of the river and its erosive force (such as in the case of the Manohara, see image), they protect it by makeshift bamboo levees filled with sand sacks, gabion walls and levees (see image from the Manohara settlement, Figure $6)$.

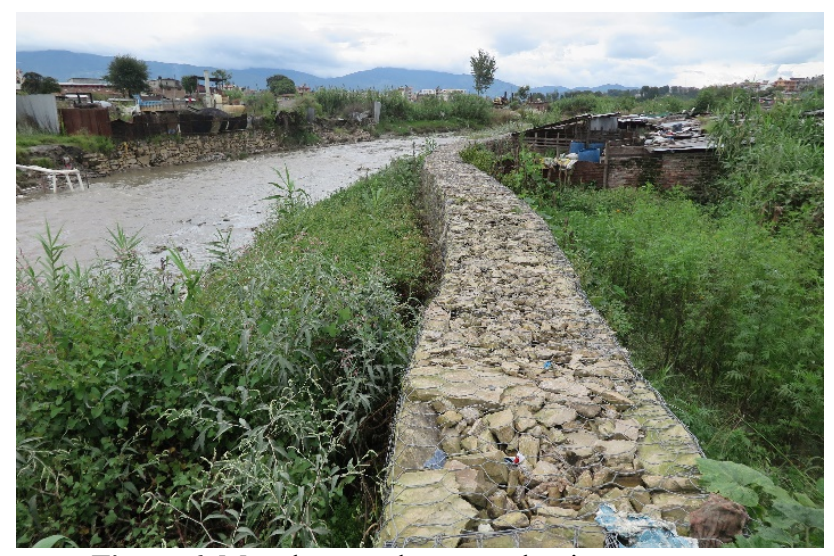

Figure 6. Manohara settlement - the river

The communities are trying to collect sufficient funds for the construction of bridges or levees through selfhelp. In the Manohara community, for instance, more affluent households contribute NPR 1,000 per month to a common fund; at present, this financial advance shall be used to repair the bridges that collapsed during a flood in August 2019 (see image) or to build roads in the slum.

Flood aid for the communities, managed by the squatters' platform, focuses on the neediest and is organised along two lines: flood protection (purchase of bamboo and materials to fortify and raise the banks) and the aid for flood victims are funded, and dangerous areas on the riverbanks are eliminated where during floods accidents or fatalities might happen (installation of rails along the slippery banks). The slum king together with his team decide to what areas and in what form the platform's aid will be sent. However, the decision is based on the discussion among all representatives of the communities within the Committee.

Within the communities, the squatters themselves are trying to manage and protect from the floods through preparation and by timely moving their property to higher floors of the houses suffering from floods (if they have a house with at least 2 floors) or elsewhere safe. They help one another without emphasising caste ranks, probably also because in the slums, only the poorest people live from the lowest castes from different areas of Nepal. In case of imminent danger, they monitor the water level, warn one another, ring the bells, visit one another and pack the belongings of the absent inhabitants to move it to safety.

The police usually arrives at the slum when there is not much time left for evacuation and the flood wave is very near, so that the squatters must rely on their own "guards". The most effective measure to mitigate the floods would be continuous extraction of sediments from the river bottom as the bottom progressively rises due to heavy sediment build-up, which causes the river to flood the banks more frequently and change its course, also in the direction to the slums. However, this possibility is strictly forbidden by the state and violation is penalised because the government fears that if sediment extraction from the Bagmati river bottom was allowed, it would uncontrollably rise aiming at the commercialisation of the extracted sand. In this way, the existing water-related structures such as bridges, levees or riverbank fortifications in the city could be threatened.

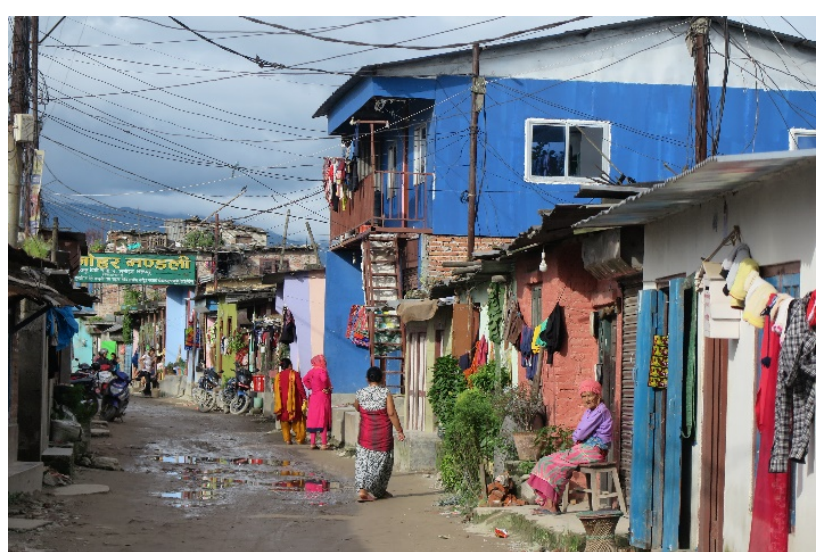

Figure 7. Manohara settlement - the people 
Even though the "slum king" himself does not share this opinion (however, he lives in the Buddha Nagar Toll Ward slum, Shankhamul, a stable squatter community that has been living in place for 42 years, in a 5-floor-building outside the flood zone), most of the respondents think that the floods and related erosive effects of the river are a severe and ever increasing risk.

According to the Secretary of the Committee, Mrs. Bhagawati Karki, climate change has started to affect also the weather in the Kathmandu Valley: the frequency of rains is increasing, and they are becoming heavier than they were some 5 years ago.

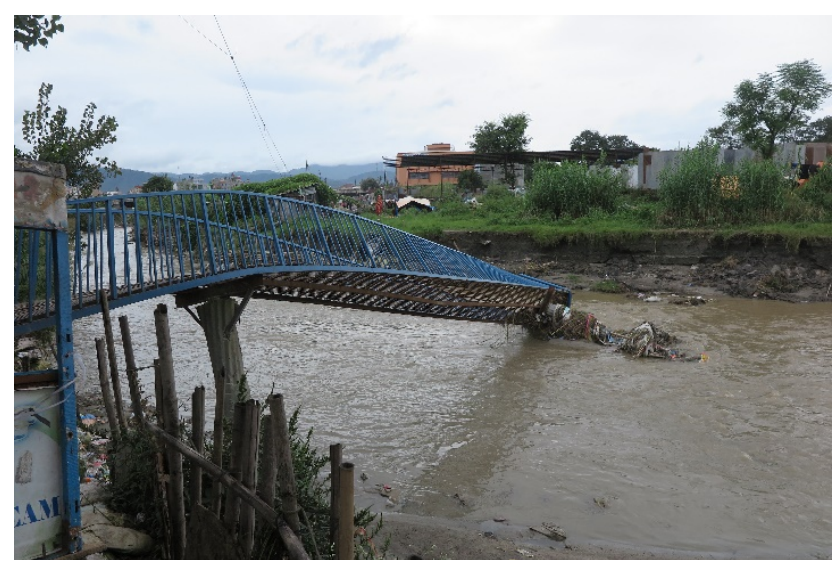

Figure 8. Manohara - the bridge damaged by the floods in the summer 2019

Within the communities, groups are being established which are trying to focus on flood prevention and management. In the Manohara community, these include e. g. the Manohara Champion Committee, which consists of 30 people who engage in spreading information about floods as well as the possibilities of their prevention and mitigation, and together with the Red Cross, organise training courses for the squatters on how to evacuate, mobilise resources, maintain the warning systems in the slums and cooperate with the police in times of highseverity events (that is during floods and/or earthquakes).

Findings from interviews and observations show many of informal settlers in the study area are affected by flood incidents. Most of flood incidents occurred during monsoon season from June to September. During this season, Kathmandu receives major portion of its annual rainfall causing increase in water level in the rivers. The rivers also collect storm water from the city through drains contributing in river level rise [3].

\section{Dang valley}

In the countryside, on the other hand, the causes of the floods are different. We set out for the Dang valley in the southwest of Nepal, through which the Babai river with 11 tributaries flows, carrying water from the surrounding mountains and hills. The Dang valley suffers from regular floods both in areas of its tributaries and at their confluences with the Babai river. During the floods, the river expands dramatically and destroys everything that stands in its way.
In the Tulsipur region, we researched two communities that were severely affected by the floods in 2014 and 2017. The community in Motipur is large, having 619 inhabitants as of summer 2018. This community is used to having the attention of donors both from Nepal and abroad, so that the welcome ceremony was well arranged and based on the appearance of Motipur's leader, Mr. Tilak Bahadur Basnet. He presented a hand-written speech several pages long, which had probably been heard by a number of foreign visitors already.

The interest in Motipur is justified: in 2014, 2 people were killed, and 49 houses destroyed by a flood.

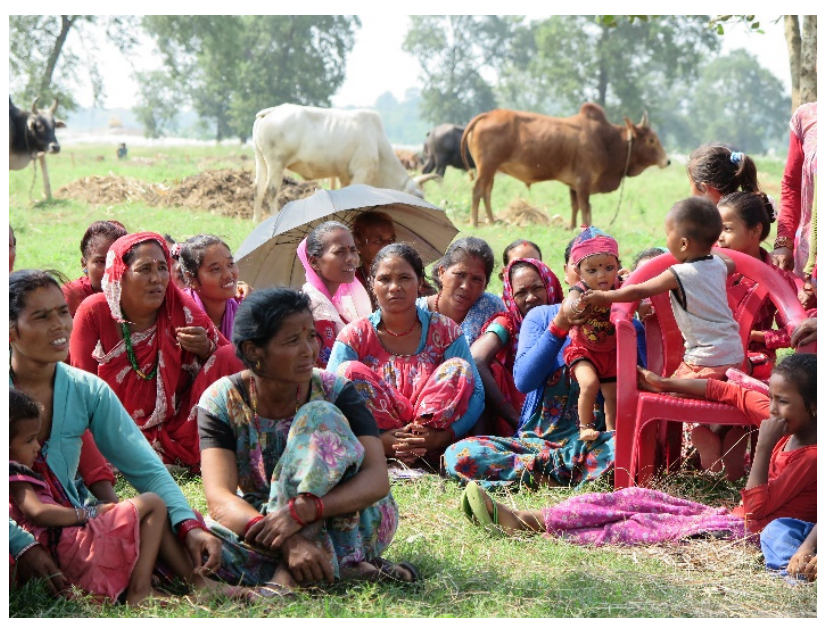

Figure 9. Motipur community meeting

Based on the flood experience, a flood prevention action plan was created in cooperation with the District Emergency Operational Centre, Dang. In addition, Flood Disaster Management Committee of Motipur was set up consisting of various groups to ensure communication in times of flood danger and the residents' preparedness for emergency situations as well as to perform the rescue operations themselves and the quantification of damage, if there is any. Thanks to the government as well as local and international donors, the village, its damaged roads and irrigation ditches were renovated, and the construction of a levee was launched in 2017.

Apart from climate change, which impacts the monsoon rainfall patterns, the main causes of the disastrous floods in Motipur have been given as follows: deforestation of the hills above Motipur, limestone extraction and, above all, farmland abandonment. Due to the migration of younger people to cities and for betterpaid jobs abroad, for instance in the United Arab Emirates, the agricultural land lays fallow and soil permeability decreases. In addition, without maintenance, the irrigation ditches become clogged and constitute a secondary cause of flooding.

Fulvari, another community in the Tulsipur region, is one of the many small communities affected by the floods that, however, is not sufficiently assertive to direct the attention of the Nepalese donors to its problems and therefore depends on damage compensation by the state. Nevertheless, the Fulvari residents are not satisfied with the way this compensation is carried out, as they obtained only a small portion of the financial aid for the reconstruction or construction of new houses that had been 
promised to them. As a result, they still live in damaged houses that may collapse at any time, or they had to abandon their homes and move to makeshift shelters or even sleep in the community woods.

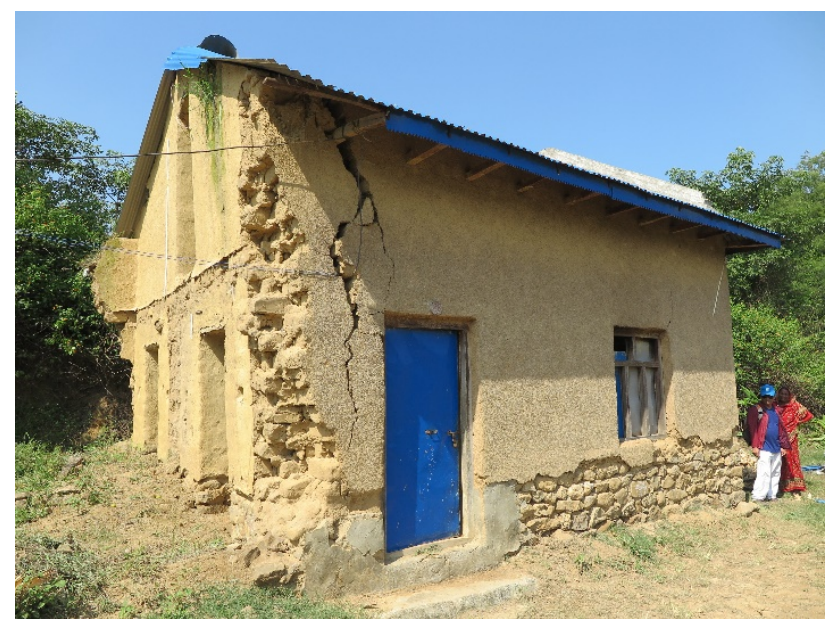

Figure 10. Fulvari

We visited Tulsipur's head, Mr. Ghanshyama Padney, to find out how the flood situation and its solution is viewed by a local leader. The most crucial problem is the abandonment of farmland. Therefore, he welcomes a new law that encourages the rental of farmland through a system of subsidies. He hopes that another system will be in place in the future that would monitor the effectiveness of the flood damage compensation by the state and would oversee the distribution of these aids. At the present time, 70 to $80 \%$ of flood victims are the same people.

Land ownership is very important in rural Nepal, as land is passed down through generations. Even if a family moves away from the flood plain, they will not give up the land. This has a positive aspect because land is not sold to development companies and built up as is the case in bigger towns.

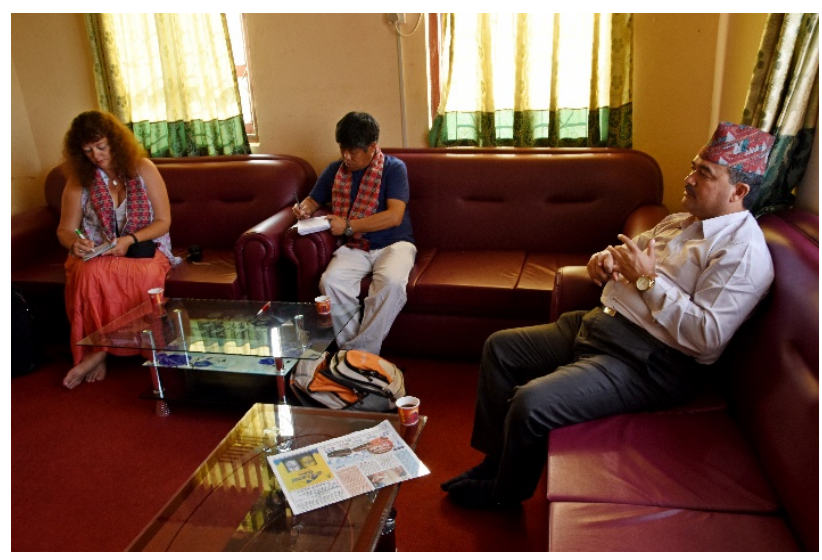

Figure 11. Discussion with Mr. Ghanshyama Padney

\section{Conclusions}

Civil engineering or nature based flood control measures can protect riverside communities from floods, but this is not the common practice in the countryside, yet. Of course, some exceptions exists in the case of the engineering measures (as for example in Motipur area), but these measures are not strategically planned what could affect their efficiency. This is the big challenge for the new „Flood risk management” law to be successfully applied in the country.

On the other hand, the nature based flood control measures are sometimes successfully used in the city area and surroundings. They could be in some cases "in the right place at the right time", for example in the area of Marga Tole - 10 community area, Kathmandu, near Baghmati river. However, in these areas, where the poor people and migrants live in slums, mostly on land they do not directly own, they does not to put so much efforts to protect their dwellings. Their activities are limited to political protests and aid applications; own investments are out of question. They are waiting for the solutions to be provided and financed by the government or city. But the government is not respecting their dwellings, when the flood protective measures are constructed in the slum area (like it was presented before, in the case of the Jagriti Basti community settlement). Thus it is highly probable, that for the migrants and illegal settlements in the Kathmandu valley, the new "Flood risk management" law for handling flood risks will not be effective if used.

The accompanying problem is as wells, that landuse planning and environmental education are insufficient in Nepal and have not become a priority, yet (Boukalova at all, 2019).

\section{Acknowledgements}

This paper was developed thanks to the INTERCOST project LTC18025 Land4Flood, financed by the Ministry of Education, Young and Sports, Czech Republic and thanks to the E!11705 EUREKA project FORMTES, financed by the Ministry of Education, Young and Sports, Czech Republic (50\%) and organizations VODNÍ ZDROJE a.s.

\section{References}

1. Boukalová Z. (2011). Insuring of the drinking water for the community Buddha Nagar Toll Ward, Shankhamul, Káthmándú, Nepál (2011). Report, METCENAS o.p.s. for the Ministry of Environment, Czech Republic.

2. Dangol N., Day J. (2017). Flood adaptation by informal settlers in Kathmandu and their fear of eviction; Safety and Security Eng. 7(2): 147-156 (C) 2017 WIT Press.

3. Lumanti Support Group for Shelter (2008). Status of squatter communities along the Bagmati River and its tributaries in the Kathmandu Valley. Kathmandu. Report.

4. UN-Habitat, Chapter 1: Development Context and the Millennium Agenda, The Challenge of Slums (2003): Global Report on Human Settlements - Revised http://unhabitat.org/wpcontent/uploads/2003/07/GR HS_2003_Chapter_01_Revised_2010.pdf.

5. Boukalova, Z., Těšitêl J., Gurung D.B. (2019). Constructed wetlands and their implementation on 
FLOODrisk 2020 - $4^{\text {th }}$ European Conference on Flood Risk Management

private and public land in Kathmandu valley, Nepal, WIT Transactions on Ecology and the Environment; 229, 1 - 8 . 